\title{
Relationship between Content Knowledge and Pedagogical Design Capacity of Elementary Mathematics Teachers in Gilgit Baltistan
}

\author{
Zahida Ibrahim $^{1}$ \\ Dr. Zarina Akhtar ${ }^{2}$
}

\begin{abstract}
The contradiction in the idea that a person having more knowledge can teach better, compelled to check and relate the teachers' content knowledge and pedagogical design capacity. The objectives of study were; to evaluate the content knowledge and pedagogical design capacity of elementary mathematics teachers, and to find out the relationship between both the variables along with the comparison of teachers pedagogical designe capacity with respect to experience and professional education. The population of the study included 194 teachers teaching mathematics to class $7^{\text {th }}$ in Gilgit Baltistan. A test for content knowledge and an observation sheet for pedagogical design capacity was used. The data were analyzed through mean score, Pearson product moment correlation and one way ANOVA. Results of the study revealed that teachers' professional education does not affect their teaching instructions rather their teaching experience have some effects at start of their service but have no effect later on. Keywords: Elementary Mathematics teacher, content knowledge, pedagogical design capacity
\end{abstract}

\section{Introduction}

It is a fact that education is necessary for human resource development which is the corner stone of economic and social development. Today education is accepted as the basic need of an individual. In education system along with teachers, students are the other key elements. Students' performance depends upon teachers' performance or teaching. It shows that teacher is the most essential element in teaching learning process. The teachers teaching depend on their relevant content knowledge and teaching skill. Therefore, it is clear that the teacher and teacher's knowledge play very important role in teaching learning process. There are two components of teacher's knowledge that is content knowledge and the knowledge of teaching skill. Content knowledge is the body of information that teachers teach and students are expected to learn.

\footnotetext{
${ }^{1}$ MS Scholar, Department of Education, IIUI, Email: zahida.ibrahim@yahoo.com

2 Assistant Professor, Department of Education, IIUI, Email: zarina.akhtar@iiu.edu.pk
} 
Generally, it refers to the facts, concepts, theories and principles that are taught and learned rather than relevant skills. Content knowledge on the other hand is "what" of teaching (Reform, 2013). Teaching skill is "how" of teaching. Knowledge of teaching skill and its concept have been kept changing with the time and need. Previously, it was known as pedagogy, the knowledge of different theories and tactics of teaching to apply on different learners in different situations. Pedagogy is the combination of teachers' content knowledge and teaching skills used for teaching which termed as pedagogical content knowledge. Now with the paradigm shift in the concept of teacher as facilitator and designer; teaching skill is transformed into teachers pedagogical design capacity. Pedagogical design capacity is to project an interactive and interesting instructional environment using the available resources.

The competent mathematics teachers identify and use students' mathematical thinking in their instruction. When teachers know and use the factual understanding of their students, they decide how to use it in planning, teaching and communicating with students. Teachers also learn about the understanding and thinking level of students. In this way teaching becomes a learning activity. This type of instruction can become generative (Fennema, Carpenter, Levi, Franke, \& Jacobs, 1996). This concept became the base of teachers pedagogical design capacity. According to the present paradigm shift in education, the teachers' role is like a facilitator. Now rather than transferring knowledge and information, the teachers create a learning context and guide students thinking. The teachers' role in mathematics classroom became constantly increasing their own knowledge of how students think and craft such an environment that develop students' mathematical thinking and increase active participation in class. Teachers having the knowledge of students thinking, use such tactics that involve all the students in solving math questions, make them able to develop their mathematical knowledge and create a learning environment where all students are able to participate and motivated towards mathematics (Carpenter, Fennema, Franke, Levi, \& Empson, 1999).

Pedagogical design capacity is "ability to perceive and mobilize existing resources in order to craft instructional contexts" (Brown \& Edelson, 2003). Perceive means the ability to recognize and notice possible resources and mobilize means the teachers' ability to use those resources in teaching (Remillard, 2005). Perceptions are amalgamation of personal beliefs and experiences which develop according to time and place. The expert teachers perceive students' mathematical thinking as a valuable resource and mobilize it to craft instructional context. 
Pedagogical design capacity represents teachers' ability to notice resources, making right decisions, and execute the plans. Two teachers having same content knowledge and skill can produce different enacted curricula, "because they possess very different capacities to create deliberate, productive designs" (Brown, 2009). Experts use the word pedagogical design instead of pedagogical knowledge by understanding the dynamic of teaching as constructive process. Expert teachers perceive and use comprehensive teaching materials and students' knowledge as a tool to respond their students' mathematical problems.

There is a general belief that one who knows best can teach best. This belief indicates that effective teaching only depends upon teachers content knowledge but there are other beliefs also. Teachers knowledge of a subject and knowledge of its demonstrations are content knowledge while a teacher's capacity to perceive and mobilize existing resources in order to craft instructional episodes is pedagogical design capacity. According to Brown (2009) teaching is a design activity in which teachers evaluate their resources and make decisions in an effort to achieve instructional goals. Content knowledge is related to cognitive knowledge while pedagogical design capacity is to deliver that knowledge by using available resources. It is clear that content knowledge and pedagogical design capacity are the main components of effective teaching. Every teacher having rich content knowledge may not possess the capacity to pedagogically design it like every rich person does not possess the capability to dispense the wealth. Hence, there is need to find out the relationship between content knowledge and pedagogical design capacity so that it can be enhanced through professional developments and trainings.

\subsection{Objectives of the Study}

Objectives of the study included to;

1. evaluate the content knowledge of elementary mathematics teachers.

2. investigate the pedagogical design capacity of elementary mathematics teachers.

3. find out the relationship between content knowledge and pedagogical design capacity of elementary mathematics teachers.

4. compare the pedagogical design capacity of elementary mathematics teachers having different professional education and teaching experience.

\subsection{Research Hypotheses}

In order to achieve objective number 3 and 4, following null hypothesis were tested;

$\mathrm{H}_{01 \text { : }}$ There is no significant correlation between content knowledge scores and pedagogical design capacity scores of elementary mathematics teachers. 
$\mathrm{H}_{02}$ : There is no significant difference among pedagogical design capacity scores and professional education scores of elementary mathematics teachers.

$\mathrm{H}_{03}$ : There is no significant difference among the scores of pedagogical design capacity and teaching experiences of elementary mathematics teachers.

\subsection{Significance of the Study}

The better understanding of relationship between elementary mathematics teachers' content knowledge and pedagogical design capacity will have implications in teachers' recruitment and training. The study results might also be beneficial to teacher resource centers, elementary schools administration and researchers. It will be helpful in teachers' selection and professional development and to provide instructional materials to teachers. The teacher resource centers will attain awareness about pedagogical design capacity for providing instructional materials to the teachers and support for different kinds of artifacts used in teaching. The results of this study might open up new avenues of research on teaching.

\subsection{Delimitations of the study}

The study was delimited on following aspects;

1. Teachers teaching mathematics to class $7^{\text {th }}$ in Baltistan

2. Algebra content (types of algebraic expression, algebraic operations and factorization) of class $7^{\text {th }}$.

\section{Review of Literature}

Content knowledge is the body of information that teachers teach and students are expected to learn in a given subject or content area Content knowledge addresses what to teach. Teachers cannot teach what they do not know therefore, the appropriate content knowledge is very important for teachers. A research study on "Content knowledge for teaching" found that teachers must know the subject they teach. Without strong content knowledge a teacher may not be competent and proficient (Ball, Thames, \& Phelps, 2008).

Research studies have shown that the level of content knowledge that Mathematics teachers possess strongly influence their way of teaching. The study on mathematical knowledge and its relationship to instruction found that teachers' mathematical knowledge strongly influence on their instruction. The competent mathematics teachers can use relevant examples to clear the topic to students and facilitate students to learn and solve questions themselves. Using their mathematical knowledge, teachers keep their students active and practical (Sowder, Philipp, Armstrong, \& Schappelle, 1998). The mathematics teachers should not only learn important mathematics but they should also possess the ability to impart their own knowledge to the students by using different 
instructional tools and methods (Papick, 2011). It is further stated that there is a large gap between the real and ideal content knowledge of mathematics teachers.

Shulman (1986) viewed that knowledge base of teaching rested at the intersection of content and pedagogy and defined pedagogical content knowledge as teachers' interpretations and transformations of subject matter knowledge in the context of facilitating student learning. He elaborated, "those who understand: knowledge growth in teaching" proposed seven components of the knowledge for teaching. (1) Content knowledge; (2) understanding of students' conceptions of the subject learning and teaching implications that were associated with the specific subject matter; (3) Knowledge of teaching strategies or pedagogy; (4) Curriculum knowledge; (5) knowledge of educational contexts; (6) Knowledge of the purpose of education (7) Pedagogical content knowledge.

On the bases of Shulman (1987) pedagogical content knowledge concept, many researchers tried to find out the knowledge necessary for teaching mathematics. Ma conducted a study and deduced a new concept of teachers' mathematics knowledge named profound understanding of fundamental mathematics. It means teachers' knowledge and ability of deep content understanding and their ability to find connection between the topic and other concepts and to use them in their teaching (Ma, 1999). Ball, et al. (2008) conducted a study and created the term "mathematical knowledge for teaching" and developed a model. In that model teachers' subject matter knowledge is divided into three categories; common content knowledge, specialized content knowledge and knowledge at the mathematical horizon. The common knowledge of mathematics is for all, while teachers need specialized content knowledge. The second domain pedagogical content knowledge also consists of three domains; knowledge of content and student, knowledge of content and teaching and knowledge of curriculum. Knowledge of content and student means to teach a topic according to the students' psychology. Knowledge of content and teaching is to design the content for better dissemination and quick understanding. Knowledge of curriculum is the educational philosophy of that subject (Ball, Thames, \& Phelps, 2008).

Brown and Edelson (2003) introduced pedagogical design capacity as "Teachers must perceive and interpret existing resources, evaluate the constraints in classroom, balance tradeoffs, and devise strategies all in pursuit of their instructional goals. These are all characteristics of design". Pedagogical design capacity is described as an "ability to perceive and mobilize existing resources in order to craft instructional contexts" (Brown, 2009). Pedagogical design capacity is the ability to identify the available related resources and practically use them in teaching process or in classroom setting (Remillard, 2005). The key dimensions 
of pedagogical design capacity are knowledge, perceptions and mobilization of curricular resources; knowledge, perceptions and mobilization of student resources; beliefs, goals, tolerance for discomfort, teaching experience and subject matter knowledge (Land, 2011).

The selection and use of the resources depend on teachers' ability to create a thoughtful and useful teaching design. Therefore, two teachers having same content knowledge and skill can produce different enacted curricula. (Brown, 2009). The study on "Promoting Pedagogical Design Capacity through Teacher's Narratives" found that every teacher has his own teaching tactics and design. Every teacher uses curriculum materials differently (Devis, Beyer, Forbes, \& Stevens, 2007). In teaching learning process the instructional materials acts as a catalyst and there is a relationship between teacher and tool. The efficient use of these tools depends on the teachers' ability to perceive and mobilize existing resources.

\subsection{Research Design}

\section{Research Methodology}

Mix methods approach was used to conduct the study. According to the information provided by education management information system department of education Gilgit Baltistan, there were 124 middle and 70 high schools in Baltistan and every school has one mathematics teacher. Therefore, the population of this study was 194 teachers teaching mathematics to class $7^{\text {th }}$ in Baltistan. According to Pandya (2010), the sampling technique for observation should be purposive sampling. Therefore the researcher selected $30 \%$ of the population by taking every fourth mathematics teacher through systematic random sampling technique. As a result the sample for this study was 58 teachers teaching mathematics to class $7^{\text {th }}$ in Baltistan.

\subsection{Instrumentation}

Two instruments were used:

1. Test from algebraic content for content knowledge score

2. Observation sheet for pedagogical design capacity score

The researcher prepared test of algebraic operations, types of algebraic expressions and factorization from teachers. The test has multiple choice questions based on factual, conceptual and procedural knowledge of algebra. To obtain the pedagogical design capacity score, an observation sheet adapted from Gencturk (2012) and Land's (2011) research instrument of teachers' pedagogical design capacity was used as research instrument. The test reliability was calculated by test-retest method, the instrument was found reliable at 0.81 reliability coefficient and both instruments were validated before data collection. 


\subsection{Data Collection}

The researcher approached the EDO office of Gilgit Baltistan, with their cooperation, test was taken by teachers and to fill the observation sheet of pedagogical design capacity of teachers, the researcher personally observed the classrooms during teaching.

\section{Data Analysis \& Results}

Content knowledge and pedagogical design were the two variables under consideration. Test was used to calculate the content knowledge score and observations were done to find out the pedagogical design capacity scores of mathematics teachers. The analysis of data presented in following tables.

Table 1 Content Knowledge test scores of elementary mathematics teachers

\begin{tabular}{ccccc}
\hline $\mathrm{N}$ & $\begin{array}{c}\text { Minimum } \\
\text { Achieved } \\
\text { Score }\end{array}$ & $\begin{array}{c}\text { Maximum } \\
\text { Achieved Score }\end{array}$ & $\begin{array}{c}\text { Calculated } \\
\text { Mean }\end{array}$ & $\begin{array}{c}\text { Standard } \\
\text { Deviation }\end{array}$ \\
\hline 58 & 4 & 15 & 11.07 & 2.35 \\
\hline
\end{tabular}

Table 1 show that the teachers have high content knowledge as the calculated mean (11.07) is higher than the actual mean (7.5). The large difference in the maximum and minimum achieved score shows that there is variation in teachers' content knowledge. The reason may be their qualification.

Table 2 Pedagogical Design Capacity Scores of Elementary Mathematics Teachers

\begin{tabular}{ccccc}
\hline $\mathrm{N}$ & $\begin{array}{c}\text { Minimum } \\
\text { Achieved } \\
\text { Score }\end{array}$ & $\begin{array}{c}\text { Maximum } \\
\text { Achieved Score }\end{array}$ & $\begin{array}{c}\text { Calculated } \\
\text { Mean }\end{array}$ & $\begin{array}{c}\text { Standard } \\
\text { Deviation }\end{array}$ \\
\hline 58 & 34 & 63 & 48.26 & 7.105 \\
\hline
\end{tabular}

Table 2 shows that the elementary mathematics teachers have high pedagogical design capacity; as the calculated mean (48.26) is higher than actual mean (37.5). The teachers differ in pedagogical design capacity as there is a large difference in the maximum and minimum achieved scores with the standard deviation of 7.105. It may be due to their qualification and experience.

Table 3 Relationship of Pedagogical Design Capacity and Content Knowledge

\begin{tabular}{llcc}
\hline \multicolumn{1}{c}{ Groups } & $\mathrm{N}$ & $\mathrm{r}$ & $\mathrm{p}$ \\
\hline $\begin{array}{l}\text { Content Knowledge } \\
\text { Pedagogical design }\end{array}$ & 58 & .103 & .441 \\
Capacity & & & \\
\hline
\end{tabular}


The value of Pearson's correlation $(\mathrm{r}=.103)$ and corresponding $\mathrm{p}$-value (.441) indicates that there is no significant relationship between content knowledge and pedagogical design capacity of teachers. So the null hypothesis "There is no significant relationship between content knowledge scores and pedagogical design capacity scores of elementary teachers" is accepted. It indicates that the teachers, who know mathematics, are not necessarily able to teach it in the best way.

Table 4 Mean scores of Professional Education and Pedagogical Design Capacity

\begin{tabular}{cccc}
\hline Groups & N & Mean & Std. Deviation \\
\hline No Professional Education & 7 & 47.14 & 3.891 \\
CT & 9 & 46.59 & 6.972 \\
B.Ed. & 32 & 47.00 & 6.984 \\
M.Ed. & 10 & 54.30 & 7.025 \\
\hline
\end{tabular}

Table 4 shows that the scores on pedagogical design capacity of teachers do not differ according to their professional education as the calculated mean values are approximately similar except M.Ed. degree teachers who have a bit higher mean score. The mean score and standard deviation on pedagogical design capacity of CT and B.Ed. teachers look approximately equal; it shows that in Gilgit Baltistan, these degrees are working at the same level. Although the mean score of teachers having no professional education is also equal to B.Ed. teachers but the difference in standard deviation shows it may be the teacher's variant ability to perform as a teacher. It indicates that only M.Ed. level professional education is effective for teaching elementary mathematics in Gilgit Baltistan. There are more than two groups of professional education therefore the groups are analyzed by applying ANOVA.

Table 5 ANOVA Summary Table

\begin{tabular}{lccccc}
\hline & Sum of Squares & df & Mean Square & F & Sig. \\
& & & & & \\
\hline Between Groups & 441.275 & 3 & 147.092 & 3.261 & .028 \\
Within Groups & 2435.846 & 54 & 45.108 & & \\
Total & 2877.121 & 57 & & & \\
\hline
\end{tabular}

Table 5 indicates that there is a significant difference in mean pedagogical design capacity scores among different professional education groups because Value of F (3.261) and corresponding p-value (.028) is significant. So the null hypothesis is not accepted. As the scores found significantly different in the 
professional education of teachers so there is a need to run a post hoc test for multiple comparison.

Table 6 Post Hoc Tests

\begin{tabular}{lcc}
\hline Groups & Mean & p-value \\
\hline M.Ed. vs. No Professional Education & 7.157 & .035 \\
M.Ed. vs. B.Ed. & 7.411 & .020 \\
M.Ed. vs. B.Ed. & 7.300 & .004
\end{tabular}

Table 6 reflects that the teachers having M.Ed. professional education are significantly different from the teachers having B.Ed., C.T. and no professional education.

The other variable is experience. There are three groups of experience levels. The difference in pedagogical design capacity of elementary mathematics teachers with respect to their experience is presented in the following table.

Table 7 Mean scores of experience and Pedagogical Design Capacity

\begin{tabular}{lcc}
\hline Groups & N & Mean \\
\hline 1-5 Years & 23 & 48.09 \\
6-10 Years & 21 & 47.19 \\
$11-15$ Years & 14 & 50.14
\end{tabular}

Table 7 indicates that the pedagogical design capacity of teachers does not differ according to the teaching experiences as the calculated mean scores are approximately similar but the teacher having 11-15 years teaching experience shows a little higher mean score. It identifies that teachers having 11-15 years teaching experience have higher pedagogical design capacity. Although the mean score of teachers having experience between 1-5 years is at second level, this may be due to their interest and fresh induction in teaching profession. It also indicates that the fresh teachers may be more aware of pedagogical design capacity.

Table 8 ANOVA Summary Table

\begin{tabular}{lccccc}
\hline & Sum of Squares & df & $\begin{array}{c}\text { Mean } \\
\text { Square }\end{array}$ & F & Sig \\
\hline Between Groups & 74.342 & 2 & 37.171 & .729 & .487 \\
Within Groups & 2802.778 & 55 & 50.960 & & \\
Total & 2877.121 & 57 & & & \\
\hline
\end{tabular}

The value of $\mathrm{F}(.729)$ and corresponding p-value (.487) shows that there is no significant difference in the mean pedagogical design capacity scores of teachers 
among the three levels of experience. So the null hypothesis "There is no significant difference among pedagogical design capacity and teaching experience of elementary mathematics teachers" is accepted. The F value is not significant therefore there is no need to apply post-hoc tuky test.

Table 9 Teachers having M.Ed. professional education, their content knowledge and pedagogical design capacity scores with respect to their work experience

\begin{tabular}{lccc}
\hline Experience & $\mathrm{N}$ & $\begin{array}{c}\text { Content Knowledge } \\
\text { Mean Score }\end{array}$ & $\begin{array}{c}\text { Pedagogical Design } \\
\text { Capacity Mean score }\end{array}$ \\
\hline 1-5 Years & 2 & 11 & 56.50 \\
6-10 Years & 5 & 12 & 50.20 \\
11-15 Years & 3 & 12 & 60.66 \\
\hline
\end{tabular}

The mean score of content knowledge shows that the teachers content knowledge score slightly increase with experience. The teachers pedagogical design capacity score is high in the first five years then from 6-10 years it decreases but from 11-15 years it again increases. The reason may be due to fresh professional training the teachers' pedagogical design capacity is high in the first five beginning years and low in next five years (i.e. 6-10 years). Table further show with the increase in experiences the teachers' pedagogical design capacity increases.

Table 10 Teachers having B.Ed. professional education their content knowledge and pedagogical design capacity scores with respect to their experience

\begin{tabular}{lccc}
\hline Experience & $\mathrm{N}$ & $\begin{array}{c}\text { Content Knowledge } \\
\text { Mean Score }\end{array}$ & $\begin{array}{c}\text { Pedagogical Design } \\
\text { Capacity Mean score }\end{array}$ \\
\hline 1-5 Years & 10 & 10.8 & 46.30 \\
6-10 Years & 11 & 11.6 & 47.40 \\
11-15 Years & 11 & 10.8 & 47.30
\end{tabular}

The content knowledge of elementary mathematics teachers having B.Ed. professional education and 6-10 years of experience is slightly high but the teachers having 1-5 and 11-15 years teaching experience have a low content knowledge. It may be due to changes in content (syllabus) as the teachers' content knowledge test is taken from the current $7^{\text {th }}$ class mathematics course. The pedagogical design capacity of teachers having B.Ed. professional education increases with experience. 
Table 11 Teachers having certificate of teaching (CT) professional education their content knowledge and pedagogical design capacity scores with respect to their experience

\begin{tabular}{lccc}
\hline Experience & $\mathrm{N}$ & $\begin{array}{c}\text { Content Knowledge } \\
\text { Mean Score }\end{array}$ & $\begin{array}{c}\text { Pedagogical Design } \\
\text { Capacity Mean score }\end{array}$ \\
\hline 1-5 Years & 6 & 8.5 & 47.80 \\
6-10 Years & 3 & 11 & 45.00 \\
11-15 Years & 0 & 0 & 00.00 \\
\hline
\end{tabular}

Table 11 indicates inverse relationship between content knowledge and pedagogical design capacity with experience of teachers having certificate in teaching. The higher PDC scores up to five years' experience may be due to fresh professional training, more interest and because of new induction.

Table 12 Teachers having no professional education their content knowledge and pedagogical design capacity scores with respect to their experience

\begin{tabular}{lccc}
\hline Experience & N & $\begin{array}{c}\text { Content Knowledge Mean } \\
\text { Score }\end{array}$ & $\begin{array}{c}\text { Pedagogical Design } \\
\text { Capacity Mean score }\end{array}$ \\
\hline 1-5 Years & 5 & 11.6 & 48.80 \\
6-10 Years & 2 & 13.5 & 43.00 \\
11-15 Years & 0 & 0.0 & 00.00 \\
\hline
\end{tabular}

The table shows inverse relationship between content knowledge and pedagogical design capacity scores of teachers having no professional education but working more than six years in schools.

\section{Discussion}

The results of research conducted by Begle (1977) on the extent to which a teacher's knowledge of algebra and teaching methodology impart influences on their students' performance showed that there is no significant correlation between teachers' content knowledge and students' performance. It supports the current study that there is no significant relationship between the content knowledge and pedagogical design capacity of elementary mathematics teachers.

To find out the contribution of training and subject matter knowledge to teaching effectiveness Mullens, Murnane, and Willett (1996) formulated a multilevel analysis of longitudinal evidence from Belize and found that there is no relationship between teachers' pedagogical training and their teaching effectiveness. It supports the findings of the current study that the B.Ed. and certificate of teaching professional education do not have an effect on pedagogical design capacity of elementary mathematics teachers. 
Although the revised pre-service training programs are highly practical in nature but the teachers working at schools in Gilgit Baltistan have long years of experience it puts question on their training. It seems that training was theoretical and no component of pedagogical design capacity remains the focus that's why the results showed no effect of professional degree on PDC. There is need to add problem solving attributes and profound knowledge of pedagogical design capacity in prospective mathematics teachers. Prospective teachers should provide activity based teaching learning opportunity. Previously all teacher education programs were of short duration, lengthy course and less practicum. There is a lack of institutional and teacher assessment (Qasim \& Kabani, 2007).

The pedagogical design capacity scores of teachers having M.Ed. and B.Ed. professional education increases, in the beginning of the career while the pedagogical design capacity of teachers having certificate of teaching and no professional education decreases with experience. The results are in conformity with the study conducted by Ball, Thames, and Phelps (2008) which concluded that teachers' experiences show little difference in the first three years and then unlikely to change after that. The findings of study by Klnl and Podolsky (2016) on effectiveness of teachers revealed that teachers' performance varies at every level of experience, teachers' experiences make a difference in the beginning of the career but the effectiveness declines toward the end of the career.

Stein, Baxter and Leinhardt (1990) found that the teacher having limited content knowledge cannot link their instruction with other fields, questions and relevant real life examples. Therefore, their content knowledge cannot contribute an effective teaching. Same is the case with participants of this study as most of the elementary mathematics teachers are not subject specialist. The teachers are trained in only how to teach rather than what to teach. According to Ma (1999) and Ball, et al. (2008) teachers' deeper content knowledge affects on their instruction and its output. According to her, the mere content knowledge cannot make a difference in teaching, the effective teaching needs teachers with profound content knowledge.

\section{Conclusions}

1. There is no significant relationship between content knowledge and pedagogical design capacity scores of elementary mathematics teachers. It is concluded that the teachers who know mathematics well, are not necessarily able to teach it in the best way.

2. It is concluded that the teachers having 1 to 5 years and more than 11 years teaching experience are effective for teaching elementary mathematics in Gilgit Baltistan. 
3. It is also concluded that there is no relationship between the content knowledge and pedagogical design capacity scores of teachers having M.Ed. professional education.

4. It is concluded that no professional development takes place with reference to experience in the elementary mathematics teachers having B.Ed. professional education.

5. It is also concluded that the pedagogical design capacity does not increase with the increment in content knowledge.

\section{Recommendations}

1. Based on the conclusion it is recommended for the teachers to have a profound understanding of fundamental mathematics and mathematical knowledge for teaching that is the knowledge of content and pedagogy specific to mathematics.

2. The school administration may arrange teachers' pedagogical trainings for their professional development as it is concluded that the pedagogical design capacity of elementary mathematics teachers does not show any progress with respect to their teaching experience.

3. The teacher resource centers may offer the teachers easy and quick access to available resources so that teachers may bring out their pedagogical design capacity.

4. The teachers' recruitment and training centers may examine the structure and content of training programs and increase the practical dimensions.

\section{References}

Ball, D. L., Thames, M. H., \& Phelps, G. (2008). Content knowledge for teaching. Journal of Teacher Education, 59(5), 389-407.

Begle, E. G. (1977). Teacher Knowledge and student achievement in Algebra. National council of Teachers of mathematics, 8(3), 216-222.

Brown, M. (2009). Mathematics Teachers at work; connecting curriculum materials and classroom instruction. New York: Routledge.

Brown, M., \& Edelson, D. C. (2003). Teaching as Design. Chicago: Letus REport Series.

Carpenter, T. P., Fennema, E., Franke, M. L., Levi, L., \& Empson, S. B. (1999). Children's Mathematics: Cognitively Guided instruction. (N. H. Heinemann, Ed.) 
Fennema, E., Carpenter, T. P., Levi, L., Franke, M. L., \& Jacobs, V. R. (1996). Longitudinal Study of Learning to Use Childrens' Mathematical Thinking in Mathematics Instruction. Journal for Research in Mathematics Education, 4(27).

Gencturk, Y. C. (2012). Teachers Mathematical Knowledge for Teaching, Instructional Practices and Students outcomes. Urbana: University of Illinois.

Klnl, T. \& Podolsky,A. (2016). Does Teaching Experience increase Teacher Effectiveness? A review of the research. Learning Ploicy Institute.

Land, T. J. (2011). Pedagogical Design Capacity for Teaching Elementary Mathematics: A cross-case analysis of four teachers. Draduate Theisis and Dessertation lowa state university, 50-160.

Ma, L. (1999). Knowing and teaching elementary mathematics: Teachers' understanding of fundamental mathematics in China and the united states. Mahwah: Lawrence Erlbaum Associates; Inc.

Mullens, J. E., Murnane, R. J., \& Willett, J. B. (1996). The contribution of training and subject matter knowledge to teaching effectiveness: A multilevel analysis of Longitudinal avidence from Belize. Comparative educatio review, 40(2), 139-157.

Pandya, S. R. (2010). Educational Research. New Delhi: S.B. Nangia.

Papick, I. J. (2011). Strengthening the mathematical content knowledge of middle and secondary mathematics teachers. Notices of the AMS, 58(3), 389-392.

Qasim, S. A., \& Kabani, A. (2007). Pakistan teacher education and professional development program. Retrieved March 20, 2016, from http://pdf.usaid.gov/pdf_docs/Pnadi362.pdf

Reform, T. G. (2013). Retrieved from http://edglossary.org/content-knowledge/.

Remillard, T. J. (2005). Examining Key Concepts in Research on Teachers' use of Mathematics Curricula. Review of Educational Research, 2(75). 
Remillard, J. T., \& Herbel-Eisenmann, B. A. (2010). Mathematics Teachers at work. New York, UK: Routledge.

Shulman, S. L. (1986). Those who understand: knowledge growth in teaching. American educational research association, 15(2), 4-14.

Shulman, S. L. (1987). Knowledge and teaching: Foundations of the new reform. $57(1)$.

Sowder, J. T., Philipp, R. A., Armstrong, B. E., \& Schappelle, B. P. (1998). Middle-grade teachers' mathematical knowledge and its relationship to instruction. New York: State University of New York.

Stien, M. K., Baxter, J. A., \& Leinhardt, G. (1990). subject-matter knowledge and elementary instruction. American educational research journal, 27(4), 639-663. 